sciendo Порівняльна професійна педагогіка 9(4)/2019 Comparative Professional Pedagogy 9(4)/2019

DOI: $10.2478 /$ rpp-2019-0036

$\mathrm{PhD}$ in Pedagogy, Associate Professor, SVITLANA SHUMOVETSKA

Bohdan Khmelnytskyi National Academy of the State Border Guard Service of Ukraine Address: 46 Shevchenko St., Khmelnytskyi, 29000, Ukraine E-mail: sv_shumovetska@ukr.net

\title{
SOME PECULIARITIES OF FORMING PROFESSIONAL CULTURE IN FUTURE OFFICERS IN US MILITARY INSTITUTIONS
}

\begin{abstract}
The necessity to research the problem of forming a professional culture of future border guard officers using the experience of military personnel training in the United States has been identified in the article. It has been found that professional culture and professionalism are an important part of the US military education system. The peculiarities of vocational training in the leading educational establishments of the United States of America, first of all the Military Academy (West Point, New York), have been studied. It has been determined that the priority of the academy, as a whole system of military vocational education in the USA, is attention to what is needed in the combat situation: analytical mind, leadership, theory and practice of management, knowledge of military history, operational doctrine, national defense policy, ability to plan and make decisions, perform legal duties, and abide the professional ethics. Experimental, case-based, interactive training with the extensive use of imitation devices and practical applications prevails in teaching methodology, which is needed to improve officers' ability to analyze and solve problems, effectively interact and apply operational doctrine. To enhance the level of professional culture and military identity in military schools, great attention is paid to the development of officers' intellectual potential, the ability to think and critically perceive the information needed to act in situations of ambiguity and uncertainty, to achieve intellectual superiority over the enemy. In accordance with the philosophy of military education in the United States, it is stipulated that a graduate of a military school should be first and foremost a highly intelligent person who, in many respects, must outperform a graduate of any civilian university, quickly acquire the chosen specialty. In addition to training for character education, military identity, the US military estalishments also intends to work hard to develop communicative skills and abilities through speaking and writing practice.

Keywords: professional culture, officer, US military education, methodology, military identity, leadership, military specialist, humanitarian component.
\end{abstract}

\section{АНОТАЦІЯ}

У статті визначено необхідність дослідження проблеми формування професійної культури майбутніх захисників кордону з використанням досвіду професійної підготовки військових фахівиів у США. З'ясовано, що формуванню професійної культури та професіоналізму відведено важливе місие в системі військової освіти США. Простежено особливості професійної підготовки у провідних навчальних закладах Сполучених Штатів Америки, насамперед Військовій академії (м. ВестПойнт, штат Нью-Йорк). Визначено, що пріоритетом академії, як усієї системи військової професійної освіти в США, с увага до того, що потрібно в бойовій ситуачіӥ: аналітичного розуму, лідерства, теорії і практики управління, знання військової 
sciendo Порівняльна професійна педагогіка 9(4)/2019 Comparative Professional Pedagogy 9(4)/2019

історії, оперативної доктрини, національної оборонної політики, здатності планувати та приймати рішення, виконання юридичних обов'язків і дотримання вимог професійной етики. У методииі навчання переважає експериментальне, засноване на конкретних випадках інтерактивне навчання з широким використанням імітаційних пристроїв $i$ практичних додатків, шзо необхідно для поліпшення здатності офіцерів аналізувати i вирішувати проблеми, ефективно взаємодіяти та застосовувати оперативну доктрину. Для підвищення рівня професійної культури та військової ідентичності у військових навчальних закладах велику увагу звертають на розвиток інтелектуального потенціалу офіцерів, здатності мислити та критично сприймати інформацію, щуо необхідно для дій у ситуачіях двозначності й невизначеності, для досягнення інтелектуальної переваги над противником. Відповідно до філософії військової освіти у США передбачено, що випускник військового навчального закладу повинен бути насамперед високоінтелектуальною людиною, який за багатьма параметрами має випереджати випускника будь-якого цивільного університету, швидко засвоювати обрану спеціальність. Окрім уваги до виховання характеру, військової ідентичності, у військових закладах США передбачено також посилену роботу щодо формування у майбутніх військових фахівців комунікативних навичок $і$ умінь за допомогою практики говоріння і письма.

Ключові слова: професійна культура, офічер, військова освіта США, методика, військова ідентичність, лідерство, військовий фахівець, гуманітарна складова.

\section{INTRODUCTION}

An important aspect of the study of military pedagogy is the definition of ways of forming the professional culture of future military professionals. The professional culture of the Border Guard officer is manifested in the high degree of mastering the necessary professional knowledge, skills, professional experience, adherence to the requirements of professional ethics during interpersonal professional interaction and attitude towards colleagues and work, in the use of the most rational ways and results. These issues have been the subject of ongoing research in the United States of America. In Ukraine, various aspects of improving the efficiency of institutions and organizations had been taken into consideration recently. Even before the 1980s, all studies concerning the management of organizations and various means of non-directive managerial influence were banned. Except the order and coercion, other options for the organization and operation of military structures were not even considered. They also disregarded such important components of the professional culture of the military professionals as humanistic outlook, understanding of the mission, values and norms of the professional activity, team spirit and leadership potential. That is why the study of the problem of forming a professional culture of future border defenders using the experience of professional training of military specialists in the USA is urgent and relevant today.

\section{THE AIM OF THE STUDY}

The paper is to present the experience of forming the professional culture in future officers in US military schools.

\section{THEORETICAL FRAMEWORK AND RESEARCH METHODS}

Scientists such as F. C. Annis, B. T. Caine, J. Carafano, A. Kochemc and others have considered particular aspects of the formation of the professional culture of the armed forces members. At first the researchers draw attention to the philosophy of leadership as a component of the professionalism of military specialists (F. C. Annis), the importance of 
military professionals for the functioning of the state (S. P. Huntington), the peculiarities of their leadership qualities development (M. Lagace). General issues in the organization of military education are the subject of attention by T. Caine (reveals the essence of the philosophy of military training), J. Carafano, A. Kochemc (determine the need to reform the military education), Bruce S. Rothblatt (defends the importance of the liberal education system). These studies provide an overview of the US military education system, specific approaches to specialist training, and the US Border and Customs Service.

The system of general scientific and specific methods of theoretical and empirical research, such as analysis of scientific literature on the problem, systematization and generalization of materials, logical and systematic approach has been used in the article.

\section{RESULTS}

The formation of professional culture and professionalism has been given an important place in the US military education system. A professional in the US Army is a person who has made a commitment to protect the nation, responsibly performs professional duties, and adheres to ethical standards. In the US Army, professionalism includes the following three components: competence, responsibility, and dedication. For the first time, these qualities were suggested by Huntington S. P. in his work "Soldier and State: Theory and Politics of Civil-Military Relations" (Huntington, 1957). The author notes these qualities distinguish a professional from a regular performer.

In the US Army there is a professional education program which is aimed at formation a sense of pride in one's profession and patriotism.

Its main ideas are: fostering a sense of pride in country and armed forces; formation of commitment to the ideals and values of the American way of life, belief in the exclusiveness of the socio-economic foundations of the USA; education on the history and traditions of the armed forces; formation of a corporate spirit in military personnel; daily advertising of military service (Shynkaruk, Volobuieva, \& Oleksiienko, 2018, p. 137).

Leading military training institutions are the US Military Academy (West Point, NY), the Naval Academy (Annapolis, Maryland), the Air Force Academy (Colorado Springs, Colorado), the Specialty School Air Force Operations (Hurlbert Field, Florida), Coast Guard Academy (New London, Connecticut).

In particular, one of the most famous US military educational institutions is the United States Military Academy in West Point, New York. The Academy focuses on providing students with leadership experience that involves four areas of work: training, tempering, physical and military training (United States Military Academy). The priority of the academy, as a whole system of military vocational education in the United States, is attention to what is needed in a combat situation: knowledge and analytical intelligence, leadership, theory and practice of management, military history, operational doctrine, national defense policy, planning and decision-making, legal responsibilities and professional ethics. Academic assessment is primarily about performance, with the criteria and conditions defined for each assignment.

Emphasis is placed on enhancing the ability to function effectively as a leader and team member. In the methodology of the basic training system (sergeant training) NCOES experimental, case-based, interactive training with extensive use of imitation devices and hands-on applications dominate. The second stage is training at the command and control armament school (CAS3). They use small group teaching techniques to improve the officer's ability to analyze and solve problems, communicate orally and in writing, effectively interact as a key military officer, and apply operational doctrine. Each group consists of 
twelve students from the units of combat operations, combat support, support of the military service. Is is necessary in order to stimulate multidisciplinary thinking and the doctrine of the use of combination weapons (Military Professional Education System). In order to increase the level of professional culture in military schools, great attention is paid to the development of the intellectual capacity of officers which is necessary to achieve intellectual superiority over the enemy in various operational and tactical situations. According to B. T. Caine, military educators, have drawn attention to the relative effectiveness of mechanical memory and static knowledge, as opposed to creativity and dynamic knowledge. They found that experimental, case-based training was better. Simulator (war games), service training, internships and apprenticeships are ancient practices. In the relationship between teacher and cadet, military instructors have shifted from authoritarian, directive mode to a more collaborative model of joint participation in joint expertise (Caine).

The issues of psychological foundations of management and the formation of practical leadership skills of future officers, borrowed from management are of great importance in US military educational institutions as well. Here, it is generally accepted that the development of managerial competence of officers is expanding to increase the effectiveness of the units. According to F. Annis, the actions of even NCOs - junior leaders have a strategic impact on both the success of campaigns and national security (Annis, 2018).

The methodology of training future military specialists in management skills takes into account the need to determine the commonality of personal goals and objectives of the unit and the state, to gain experience in overcoming difficulties, to learn certain algorithms and samples of necessary actions. Future military professionals are taught first of all to make tactical and operational decisions, anticipate its consequences and expediency of risk taking into account the dynamic components of the situation. The philosophy of military training, according to B. T. Caine, provides detailed reviews and analysis after action in simulated combat conditions. During such exercises, leaders' decisions and their consequences are evaluated using automated action logs, controllers' observations, and, significantly, the views of unit members. These professional collective reflections can be very humbling, but they are necessary as important lessons. Such training practices teach self-discipline and initiative, a common understanding of mission and command vision, helping to apply technology skillfully, to be mobile on the battlefield. Such a technique supports the belief in both individual uniqueness, demonstrating the skills of the team that underlies the organizational effectiveness of the US military (Caine). This helps to teach future officers to think and to take a critical view of the environment. D. Carafano and A. Koshams point out that thinking is the best preparation for a situation of ambiguity and uncertainty that may arise when planning and conducting operations (Carafano, \& Kochemc, 2005, pp. 15-19).

The priority at West Point Academy is to develop in cadets three major attributes which, according to the US military authority, must be inherent in the professional military man. They are competence, responsibility and dedication. As to the formation of the military man in the frames of "Be, Know and Do" S. Snook points out that the most difficult in terms of development is the character, understanding of the mission of the military man because the character is an important component of the leadership doctrine: who you are, your values, your worldview. S. Snook emphasizes that this component in the development of leaders is the most difficult, because it is very difficult to change a person. The author believes that a leader both a young sergeant and a senior general is one that has largely internalized all four central components of professional military identity: 1) military preparedness, 2) commitment to the nation, 3) professional, and 4) leadership potential (Lagace, 2003). 
In addition to the education of character, military identity, the leadership of the Ministry of Defense notes that the officer must also be highly intelligent, well-educated. For this reason, military disciplines in military educational establishments do not exceed $15 \%$ of the total amount of study time, in turn, humanities provide up to $50 \%$ of first-year study time, up to $30 \%$ in the second, up to $60 \%$ in the third, and up to $70 \%$ - on the fourth (Shynkaruk, Volobuieva, \& Oleksiienko, 2018, p. 136). Future military specialists study political science, the basics of economic theory, history, psychology, jurisprudence, sociology, world culture, the foundations of military leadership, logic, philosophy, racial theory, leadership theory, literature, theology, art, foreign languages extensively. Importance is given to the study of history. It is believed that «few professions make it possible to make history.

The focus on the humanitarian component is a manifestation of the American educational tradition. As American historian and educator S. Roseblatt points out, the humanitarian component of higher education has always been a priority in the United States (Rothblatt, 2003, p. 5). The researcher emphasizes that "humanitarian education is an integral part and characteristic aspect of the US education industry, as anywhere else in the world", "an eternal idea, a national emotional investment of the United States" (Rothblatt, 2003, p. 1-2). In general, the purpose of the humanities is that they help to understand the characteristics of historical and cultural development, develop the ability to analyze sociocultural problems, the ability to logically express judgments about social and cultural phenomena, actualize the values necessary for personal life.

The US military institutions also envisage enhanced work to develop communicative skills and abilities in future military professionals through speaking and writing. At the beginning of each academic year, all cadets are tested in English and then take differentiated courses to improve their writing effectiveness and use of language skills in communication. During the training cadets regularly prepare reports, write course papers and abstracts on various topics. In exams, knowledge is tested using a variety of tests, which are not aimed at determining the completeness and depth of factual information on the subject, but to identify the general education of the cadet, his ability to think independently and make decisions (Streletsky, 2006).

US educational institutions pay significant attention to creating the conditions for officers' personal development, that is, to support, as noted by F. Annis, the educational philosophy of a "learning culture" and to provide the tools necessary for the continuous improvement of individual leadership abilities. This is due to the fact that a significant increase in the roles and responsibilities of the younger leaders in the war requires a higher level of preparation for the successful accomplishment of their mission. Educational leadership supports the educational philosophy of development, agreeing that this is how soldiers can be prepared for unpredictable situations: "if our soldiers are to dominate the modern battlefield, they must be able to adapt and innovate faster than their adversary" (Annis, 2018).

\section{CONCLUSIONS}

In the US military education system, much attention is paid to shaping the professional culture and professionalism of future military professionals. At leading US educational institutions, most notably the Military Academy (West Point, New York), priority is given to what is needed in a combat situation: analytical thinking, leadership, theory and practice of management, knowledge of military history, operational doctrine, national defense policy, the ability to plan and make decisions, fulfill legal responsibilities, and adhere to professional ethics requirements. Experimental, case-based, interactive training is widely used in the teaching methodology, with the widespread use of imitation 
sciendo Порівняльна професійна педагогіка 9(4)/2019 Comparative Professional Pedagogy 9(4)/2019

devices and practical applications, which is necessary to improve the officer's ability to analyze and solve problems, effectively interact and apply operational doctrine.

To enhance the level of professional culture and military identity in military schools, great attention is paid to the development of officers' intellectual potential, the ability to think and critically perceive the information needed to act in situations of ambiguity and uncertainty, to achieve intellectual superiority over the enemy. In accordance with the philosophy of military education in the United States, it is stipulated that a graduate of a military school should be first and foremost a highly intelligent person who, in many respects, is ahead of a graduate of any civilian university, quickly acquire the chosen specialty. In addition to training for character education, military identity, the US military estalishments also intends to work hard to develop communicative skills and abilities through speaking and writing practice.

The experience of training military personnel in the United States is essential to improve the training of future defenders of the Ukrainian border.

The perspectives of further research are learning the experience of forming the professional culture of border guards in the European countries, to clarify Frontex's approaches to form the European values of border guards.

\section{REFERENCES}

1. Annis, F. C. (2018). A Better Model of Leader Development; Repairing the Education Philosophy within Army Leader Development. Retrieved from https://medium.com/ experientia-et-progressus/annis-leader-development-3e6fca77ebfc.

2. Bruce, T. Caine. (2019). Philosophy Military Training Doctrine and Practice. Retrieved from https://education.stateuniversity.com/pages/2238/Military-Training-Doctrine-/ Philosophy-Practice.html.

3. Carafano, J., \& Kochemc, A. (2005). Military Education Needs Reform. Defense News, 4, 15-19.

4. Huntington, S. P. (1957). The Soldier and the State: The Theory and Politics of Civil-Military Relations. New York: Belknap Press.

5. Lagace, M. (2003). How the U.S. Army Develops Leaders. Retrieved from https://hbswk.hbs.edu/item/how-the-u-s-army-develops-leaders.

6. Military Professional Education System. (2019). Retrieved from https://education./ stateuniversity.com/pages/2237/Military-Professional-Education-System.html.

7. Rothblatt, S. (2003). Living Arts: Comparative and Historical Reflections on Liberal Education. Washington: Association of American Colleges and Universities.

8. Streletskyi, A. (2006). Yssledovanyia v oblasty sovershenstvovanyia professyonalyzma lychnoho sostava VS USA. Zarubezhnoe voennoe obozrenye, 5. Vzyato s http://pentagonus.ru/publ/5-1-0-213.

9. Shynkaruk, O. M., Volobuieva, O. F., \& Oleksiienko, B. M. (2018). Moralnopsykholohichne zabezpechennia profesiinoi diialnosti personalu Derzhavnoi prykordonnoi sluzhby Ukrainy. Khmelnytskyi: Vyd-vo NADPSU.

10. United States Military Academy / Wikipedia: the free encyclopedia. (2019). Retrieved from https://en.wikipedia.org/wiki/United_States_Military_Academy. 